\title{
$\frac{100}{\mathrm{LuT}} \mathrm{RPES}$
}

\author{
MAREK RATAJCZAK*
}

\section{SYSTEM AWANSÓW NAUKOWYCH W POLSCE: EWOLUCJA I ASPEKTY INSTYTUCJONALNE}

\section{UWAGI WSTĘPNE}

Sejm 20 lipca 2018 r. przyjął ustawę Prawo o szkolnictwie wyższym i nauce $^{1}$, nazywaną niekiedy, z pewną emfaza, Konstytucją dla nauki, a często ustawą 2.0 czy - od nazwiska ówczesnego ministra nauki i szkolnictwa wyższego - strategią Gowina. Przyjęcie tej ustawy nastapiło prawie równo 98 lat po przyjęciu pierwszej po odzyskaniu niepodległości w 1918 r. ustawy regulującej funkcjonowanie szkół wyższych mających status akademicki. W tym miejscu warto przypomnieć otwierającą tę ustawę Preambułę, w której zawarto nadal aktualną wizję roli szkół wyższych i zadań stojących przed nauczycielami akademickimi. Początek tej Preambuły stanowił, że: „Najwyższe uczelnie, poświęcone pielęgnowaniu i szerzeniu wiedzy, noszą w Państwie Polskiem w ogólności nazwę szkół akademickich. Zadaniem ich jest służyć nauce i ojczyźnie. W tym celu mają one szukać i dochodzić prawdy we wszystkich gałęziach wiedzy ludzkiej, oraz przewodniczyć na drodze poznawania tej prawdy przez młodzież akademicka, a przez nią rozpowszechniać wśród całego narodu polskiego w imię zasad, przyświecających moralnemu i umysłowemu doskonaleniu się rodzaju ludzkiego"2.

Celem prezentowanego opracowania jest prezentacja, w wymiarze historycznym, ewolucji systemu awansów naukowych w Polsce, ze szczególnym uwzględnieniem rozwiązań z okresu po rozpoczęciu transformacji ustrojowej. Autor opracowania zamierza przy tym wykorzystać elementy analizy i aparatu pojęciowego typowego dla ekonomii instytucjonalnej, zarówno w jej wariancie określanym czasem mianem starej ekonomii instytucjonalnej, jak i tak

" Marek Ratajczak, Uniwersytet Ekonomiczny w Poznaniu, marek.ratajczak@ue.poznan.pl, https://orcid.org/0000-0003-3671-4227.

${ }^{1}$ Ustawa z 20 lipca 2018 r. - Prawo o szkolnictwie wyższym i nauce, Dz. U. 2018, poz. 1668 (dalej jako: PSW).

${ }^{2}$ Ustawa z 13 lipca 1920 r. o szkołach akademickich, Dz. U. 1920, Nr 72, poz. 494: 1. 
zwanej nowej ekonomii instytucjonalnej. To zwrócenie uwagi na perspektywę instytucjonalna jest o tyle istotne, że polska literatura odzwierciedlająca debatę o systemie awansów naukowych w swej zasadniczej części albo jest skoncentrowana na stronie formalnoprawnej, od kwestii proceduralnych począwszy, a na wykładni konkretnych zapisów legislacyjnych skończywszy ${ }^{3}$, albo polega na dzieleniu się z odbiorcami przemyśleniami i uwagami, zwłaszcza przez osoby o niekiedy znacznym doświadczeniu jako uczestnicy postępowań awansowych. W zasadzie brak opracowań, w których próbowano by spojrzeć na system awansów naukowych i jego funkcjonowanie zwiąane z realizacja procedur prowadzacych do uzyskania stopni naukowych i tytułu naukowego jako właśnie przykład funkcjonowania instytucji, a w tym w szczególności tych o charakterze nieformalnym. Chodzi przy tym o instytucje w takim znaczeniu, jakie jest najczęściej przyjmowane w ślad za Douglasem Northem, który zdefiniował instytucje jako „[...] zasady gry w społeczeństwie, a bardziej formalnie, to stworzone przez ludzi ograniczenia, które kształtują ludzkie interakcje. Tworzą więc one strukturę bodźców w procesie wymiany czy to politycznym, społecznym czy gospodarczym. Zmiana instytucjonalna kształtuje sposób, w jaki społeczeństwa ewoluują na przestrzeni czasu, i w związku z tym, jest kluczem do zrozumienia zmiany historycznej”".

\section{SYSTEM AWANSÓW NAUKOWYCH W OKRESIE II RZECZPOSPOLITEJ}

Po odzyskaniu niepodległości w 1918 r. bazą dla kształtującego się systemu stanowisk nauczycieli akademickich i awansów naukowych stały się rozwiąania zaczerpnięte z tradycji szkolnictwa wyższego w Cesarstwie Austro-Węgierskim. W jakiejś mierze było to konsekwencja tego, że to na obszarze Galicji funkcjonowały najbardziej rozwinięte elementy szkolnictwa wyższego, w którym na dodatek dopuszczalne było kształcenie w języku polskim. Wspomniana ustawa z 1920 r. jako podstawowe przewidywała stanowisko docenta oraz profesorów nadzwyczajnego i zwyczajnego. Objęcie stanowisk profesorskich następowało w drodze nominacji władz państwowych. Z kolei stanowisko docenta, zgodnie z łacińskim pierwowzorem tego terminu oznaczającym osobę ucząca, wymagało przejścia procedury habilitacyjnej, rozumianej nie jako prowadzącej do uzyskania stopnia naukowego, ale dającej uprawnienia do samodzielnego wykładania. Jednym z warunków ubiegania się o możliwość przystapienia do procedury habilitacyjnej było posiadanie dyplomu doktora. Doktorat był określany mianem wyższego tytułu naukowego (w dzisiejszej nomenklaturze stopnia naukowego, choć dość częste, nawet wśród przedstawi-

${ }^{3}$ Znakomitym przykładem takiej wykładni jest praca Huberta Izdebskiego i Jana Michała Zielińskiego (Izdebski, Zieliński 2019).

${ }^{4}$ North (1992), tłumaczenie za: North (2007): 2. 
cieli środowiska akademickiego, jest mówienie, a i pisanie, właśnie o tytule doktora), a rolę tytułu niższego pełniło magisterium.

Ustawa z 15 marca 1933 r. ${ }^{5}$ o szkołach akademickich, która zastapiła ustawę z 1920 r., nie wprowadziła istotnych zmian do systemu awansów naukowych i gradacji stanowisk nauczycieli akademickich. Stopień, a nie tytuł, doktora pozostał wyższym stopniem naukowym, a grono nauczycieli zatrudnionych na innych stanowiskach niż docenci i profesorowie określono mianem nauczycieli nieakademickich. Co warto zaznaczyć i przypomnieć, stanowiska profesorskie były generalnie powiązane z możliwościami zatrudnienia przede wszystkim w roli kierujących katedrami. Analiza rozwiązań ustawowych z okresu II Rzeczpospolitej, a także tekstów opisujących praktykę funkcjonowania szkolnictwa wyższego w tym okresie pokazuja, że zwłaszcza po wprowadzeniu ustawy z $1933 \mathrm{r}$. nasiliły się problemy związane z tym, do czego szczególną wagę przywiązuje stara ekonomia instytucjonalna, czyli relacjami władzy. Po jednej stronie były władze państwowe, które co prawda formalnie gwarantowały wolność badań i nauczania ${ }^{6}$, ale zarazem poprzez rozwiązania legislacyjne starały się zagwarantować sobie prawo daleko idącej ingerencji w obsadzanie stanowisk nauczycieli akademickich ${ }^{7}$. Po drugiej stronie była wspólnota akademicka, oczywiście niestanowiąca monolitu ani w wymiarze ideologicznym, ani z punktu widzenia stosunku do otaczającej świat akademicki rzeczywistości, dla której istotną wartością było to, co dzisiaj określamy mianem autonomii.

\section{SYSTEM AWANSÓW NAUKOWYCH W OKRESIE PRL}

Druga wojna światowa przyniosła olbrzymie i tragiczne straty w i tak dość skromnym kapitale ludzkim i intelektualnym zwiąanym z polskim środowiskiem akademickim. Dodatkowo konsekwencje geopolityczne wojny oznaczały pozostanie poza nowymi granicami Polski dwóch ważnych ośrodków akademickich, jakimi były Uniwersytet Jana Kazimierza we Lwowie i Uniwersytet Stefana Batorego w Wilnie. Ocalała kadra naukowa z tych ośrodków zasiliła zwłaszcza Uniwersytet Wrocławski i Uniwersytet Mikołaja Kopernika w Toruniu.

W początkowym okresie powojennym system awansów naukowych i stanowisk akademickich został oparty na tradycji przedwojennej, a regulujący to dekret z 28 października 1947 r. w pierwszym ustępie art. 1 gwarantował

${ }^{5}$ Ustawa z 15 marca 1933 r. o szkołach akademickich, Dz. U. 1933, Nr 29, poz. 247.

${ }^{6}$ W ustawie z 1933 r. wyeliminowano przytoczoną w początkowej części artykułu Preambułę ustawy z 1920 r., aczkolwiek jej treść w znacznej mierze wykorzystano przede wszystkim w art. 1 nowej ustawy.

7 Jednym z przykładów próby ingerencji przedstawicieli państwa w kwestie kadrowe była sprawa habilitacji Stefana Banacha, której nie chciało uznać ówczesne Ministerstwo Wyznań Religijnych i Oświecenia Publicznego. Przytoczone za: Przeniosło (2011). Ta sama autorka analizuje cały system awansów naukowych II RP w: Przeniosło (2017). 
wolność badań naukowych ${ }^{8}$. Jednakże wraz z postępującym podporządkowywaniem funkcjonowania państwa, gospodarki i społeczeństwa rozwiąaniom wzorowanym na modelu radzieckim także i w sferze akademickiej nastapiła istotna zmiana. Jej wyrazem była ustawa z 15 grudnia 1951 r. o szkolnictwie wyższym i pracownikach nauki ${ }^{9}$, która oznaczała odstapienie od wcześniejszych regulacji, począwszy od pomijającej takie kwestie, jak wolność badań naukowych, wizji roli szkolnictwa wyższego w gospodarce i społeczeństwie, a skończywszy na zupełnie nowej, opartej na nomenklaturze radzieckiej, gradacji stopni naukowych. Stopniem niższym stał się stopień kandydata nauk, a stopniem wyższym stopień doktora nauk. Zlikwidowano pojęcie habilitacji, a w ustawie znalazł się także, do dziś funkcjonujący w środowisku akademickim, choć niemający obowiązujących podstaw legislacyjnych, podział nauczycieli akademickich na samodzielnych i pomocniczych. Tymi pierwszymi określano osoby mające tytuł profesora (zwyczajnego czy nadzwyczajnego) lub docenta. Wszystkie zatrudnienia na stanowiskach samodzielnych dokonywane były na mocy decyzji ministra, któremu podlegała dana szkoła wyższa.

Jednym z wyrazów tzw. odwilży gomułkowskiej stało się przyjęcie 5 listopada 1958 r. nowej ustawy o szkołach wyższych ${ }^{10}$. Ustawa nie stanowiła przełomu w stosunku do poprzedniej regulacji z punktu widzenia wizji roli szkół wyższych ani fundamentów ideowych ich funkcjonowania. Artykuł 1 to określający był w znacznej mierze powtórzeniem zapisów tego samego artykułu ustawy z 1951 r., z pominięciem idei wolności i autonomii włącznie. De facto nie zmieniła się wizja roli państwa w stosunku do środowiska akademickiego. W kategoriach władzy to władza państwowa miała zachować nadrzędność dająca daleko idące uprawnienia dotyczące ingerencji w kwestie awansowe. Zrezygnowano z nomenklatury awansów naukowych wzorowanych na tradycji radzieckiej, przyjmując dwustopniowy system, z niewielkimi zmianami w sferze nazewnictwa, obowiązujący do dziś. Dwa stopnie naukowe obejmowały stopień doktora i stopień docenta, przy tym ten drugi był nadawany w wyniku procedury habilitacyjnej, która od tego momentu, do dziś włącznie, przestała być wyrazem uzyskiwania kompetencji dydaktycznych pozwalających na samodzielne wykładanie, a stała się kolejnym elementem w rozbudowanej strukturze formalnych awansów naukowych podporządkowanych nadzorowi państwa. Uprawomocnienie się decyzji o nadaniu stopnia naukowego docenta wymagało akceptacji ministra wspomaganego przez Radę Główną Szkolnictwa Wyższego. Ustawa dawało prawo do określenie dyscyplin, w ramach których także nadawanie stopnia doktora wymagało akceptacji ministerialnej. Również minister decydował o zatrudnieniu na stanowisku tzw. docenta etatowego, a Rada Państwa o zatrudnieniu na stanowiskach profesorów nadzwyczajnego i zwyczajnego. W kategoriach idei władzy ustawa z 1958 r. stanowiła wyraz dominacji przedstawicieli państwa, w którym choć formalnie

${ }^{8}$ Dekret z 28 października 1947 r. o organizacji nauki i szkolnictwa wyższego, Dz. U. 1947, Nr 66, poz. 415 .

${ }^{9}$ Ustawa z 15 grudnia 1951 r. o szkolnictwie wyższym i o pracownikach nauki, Dz. U. 1952, Nr 6, poz. 38 .

${ }^{10}$ Ustawa z 5 listopada 1958 r. o szkołach wyższych, Dz. U. 1958, Nr 68, poz. 336. 
zadeklarowano odstapienie od wzorca radzieckiego, to było to tylko odstapienie w sferze werbalno-organizacyjnej, ale na pewno nie $\mathrm{w}$ sferze wizji pozycji państwa w stosunku do środowiska akademickiego.

31 marca $1965 \mathrm{r}$. przyjęto pierwszą w historii odrębną ustawę o stopniach naukowych i tytułach naukowych ${ }^{11}$, która stała się pierwowzorem wszystkich, łącznie z zapisami zawartymi w ustawie Prawo o szkolnictwie wyższym i nauce z 2018 r., regulacji dotyczących awansów naukowych w Polsce. To w tej ustawie zawarta została między innymi definicja wymogów stawianych rozprawom doktorskim jako stanowiącym samodzielne (w późniejszych rozwiązaniach legislacyjnych zastapiono to określeniem „oryginalne”) rozwiązanie zagadnienia naukowego (później nazwano to „problemem”) i oczekiwań wobec kandydata wiążących się z wykazywaniem się ogólną wiedzą teoretyczna w danej dyscyplinie. Dopiero na początku lat dziewięćdziesiątych XX w. uzupełniono listę wymogów stawianych kandydatom do stopnia doktora o umiejętność samodzielnego prowadzenia pracy naukowej, a w ustawie z 2018 r. dodano zapisy nawiazujące do (budzącej wiele kontrowersji w sytuacji zachowania naukowego charakteru stopnia doktora) idei tzw. doktoratu wdrożeniowego. Podobnie zawarty w ustawie z 1965 r. stawiany kandydatom do stopnia docenta (dziś doktora habilitowanego) wymóg poważnego (w późniejszych rozwiązaniach legislacyjnych zastapiono to słowem „znaczacego”) wkładu w rozwój dziedziny nauki lub dyscypliny naukowej jest powtarzany w kolejnych regulacjach z ustawą z $2018 \mathrm{r}$. włącznie.

Ustawa z 1965 r. nie tylko nie zmniejszyła, ale wręcz zwiększyła władczość przedstawicieli państwa wobec środowiska akademickiego w sferze awansów naukowych. W odniesieniu do doktoratów ustawa przewidywała możliwość sprzeciwu wobec nadania stopnia doktora, ze strony właściwego ministra lub, w odniesieniu do części jednostek naukowych, sekretarza Polskiej Akademii Nauk, która to organizacja, powstała w 1951 r. zgodnie z wzorcami zaczerpniętymi z modelu radzieckiego, de facto była elementem systemu państwowej kontroli nad nauką i szkolnictwem wyższym ${ }^{12}$. Nadanie stopnia docenta bezwzględnie wymagało zatwierdzenia centralnego. Ustawa z 1965 r. stanowiła także, że profesura nadzwyczajna i zwyczajna stają się tytułami naukowymi nadawanymi przez ówczesną Radę Państwa na wniosek Prezesa Rady Ministrów. Ustawa o stopniach naukowych i tytułach naukowych z $1965 \mathrm{r}$. obowiązywała do końca okresu PRL. Jedyną istotną zmianą nomenklaturową było odstapienie od traktowania docenta jako stopnia naukowego i usankcjo-

${ }^{11}$ Ustawa z 31 marca 1965 r. o stopniach naukowych i tytułach naukowych, Dz. U. 1965, Nr 14, poz. 101.

${ }^{12} \mathrm{~W}$ tym miejscu warto zauważyć, że gdy na początku lat dziewięćdziesiątych XX w. nastapiła reaktywacja przedwojennej organizacji, czyli Polskiej Akademii Umiejętności, która po utworzeniu PAN w 1951 r. faktycznie, aczkolwiek nie formalnie, zlikwidowano, w znacznej mierze w celu uniknięcia nasilania się dyskusji o miejscu PAU w polskim systemie nauki w relacji do PAN, w ustawach regulujących finansowanie nauki, a w tym w ustawie Prawo o szkolnictwie wyższym i nauce z 2018 r., wprowadzono zapisy gwarantujace PAU, jako jedynemu stowarzyszeniu o charakterze naukowym, status odrębnej składowej polskiego systemu nauki i szkolnictwa wyższego, co daje podstawę do zasilania tej organizacji środkami z budżetu państwa na innych zasadach niż pozostałe funkcjonujące w Polsce stowarzyszenia naukowe. 
nowanie pojęcia doktor habilitowany jako wyrazu najwyższego ze stopni naukowych. Zmiana ta wiązała się ze stworzeniem w 1968 r. możliwości ubiegania się o stanowisko docenta osobom bez habilitacji. Chodzi o tzw. docentów marcowych, czyli element kolejnej odsłony czystek personalnych, dotyczacych, w tym wypadku przede wszystkim osób pochodzenia żydowskiego, a zarazem chęci zapewnienia przyspieszonego awansu osobom, które były traktowane przez ówczesne władze jako zaufane w kategoriach ideologicznych. Pod rządami ustawy z 1965 r., w 1973 r., powołano Centralną Komisję Kwalifikacyjną do spraw Kadr Naukowych, która funkcjonowała do roku $1990^{13}$.

Cały okres PRL, a w szczególności od wejścia w życie ustawy z 1951 r., był skażony ideą nadrzędności polityki państwa, w rozumieniu idei szerzenia określonych wzorców ideologicznych i wynikających z nich konsekwencji w sferze społecznej, gospodarczej i politycznej, nad tradycyjnymi wartościami naukowymi i akademickimi. W szczególności widoczne to było w sferze nauk społecznych i humanistycznych odpowiedzialnych w znacznej mierze za kształtowanie tego, co w nomenklaturze marksowskiej określano mianem nadbudowy. Trochę większą autonomię, co nie znaczy, że prawdziwą wolność badań, miały nauki ścisłe czy techniczne, których rozwój był postrzegany jako niezbędny dla rozwoju potencjału gospodarczego i - co nie było bez znaczenia - militarnego. Trzeba jednak także zauważyć, że na tle większości państw funkcjonujących w strefie wpływów ZSRR rozpatrywana w kategoriach poszanowania chociaż minimum niezależności sfery badawczej od nadzoru ideologiczno-politycznego, sytuacja polskich naukowców po 1956 r., także tych z obszaru nauk społecznych i humanistycznych, i tak była lepsza niż w większości pozostałych państw. Nie było niepisanego, a ściśle przestrzeganego w większości pozostałych państw tzw. bloku radzieckiego, wymogu włączania do literatury, bez względu na konkretny temat, cytatów z klasyków marksizmu-leninizmu czy dokumentów partyjnych, a w tym tekstów sygnowanych przez aktualnego przywódcę. Ale nie zmienia to tego, że na pewno nie był to czas sprzyjający rozwojowi nauki, która by się rzeczywiście rozwijać, potrzebuje wolności badań i przestrzegania przez państwo zasady subsydiarności.

\section{SYSTEM AWANSÓW NAUKOWYCH OD ROKU 1990}

Wraz z rozpoczęciem transformacji ustrojowej formalnie odrzucono rozwiązania kojarzące się z okresem PRL. W sferze awansów naukowych wyrazem tego było przyjęcie 12 września 1990 r. ustawy o tytule naukowym i stopniach naukowych ${ }^{14}$. Ustawa ta ograniczyła liczbę tytułów naukowych do jednego tytułu profesora. Pozostawiono dwa stopnie naukowe i - o czym już wspominano - w stosunku do ustawy z $1965 \mathrm{r}$. w zasadzie niewiele zmieniono

${ }^{13}$ Dodatkowe informacje o habilitacjach i profesurach w okresie PRL można znaleźć w: Wojtczak (2017) i (2018).

${ }^{14}$ Ustawa z 12 września 1990 r. o tytule naukowym i stopniach naukowych, Dz. U. 1990, Nr 65, poz. 386 . 
zapisy regulujące wymogi i oczekiwania związane z ubieganiem się o stopień doktora i stopień doktora habilitowanego. Centralna Komisja Kwalifikacyjna została zastapiona pochodząca z wyboru środowiskowego Centralną Komisja do Spraw Tytułu Naukowego i Stopni Naukowych. Co ciekawe, środowiskowy charakter Centralnej Komisji nie uchronił jej przed traktowaniem przez część środowiska jako w jakiejś mierze kontynuatorki Centralnej Komisji Kwalifikacyjnej. Zwłaszcza decyzjom niekorzystnym dla zainteresowanych towarzyszyły często zarzuty braku transparentności, obiektywizmu czy kierowania się przesłankami personalnymi. Niestety w tle jest, istotna także jako element analiz instytucjonalnych, kwestia, do której jeszcze powrócę, czyli problem zaufania państwa do obywateli, obywateli do państwa i obywateli wzajemnie wobec siebie, a w tym wypadku indywidualnych członków społeczności akademickiej wobec środowiskowych mandatariuszy, wybranych bądź co bądź z rekomendacji tegoż środowiska, do CK.

W przyjętej także 12 września 1990 r. ustawie o szkolnictwie wyższym ${ }^{15}$ zawarto jednoznaczne zapisy gwarantujące wolność badań naukowych, twórczości artystycznej i nauczania. W ramach nomenklatury stanowisk zajmowanych przez nauczycieli akademickich pozostawiono dwa stanowiska profesorskie, a wyeliminowano stanowisko docenta. Ta ostatnia decyzja była po części spowodowana konotacja ideologiczna, związaną z wskazywanym wcześniej problemem tzw. docentów marcowych. Co ciekawe, w niektórych środowiskach (np. medycznym) zwyczaj, bo nie prawo, używania określenia docent pozostał $\mathrm{w}$ stosunku do osób po habilitacji, ale niemających tytułu profesora.

Przepisy zawarte w ustawie o szkolnictwie wyższym z 1990 r. rozpoczęły, $\mathrm{w}$ przekonaniu autora, proces erozji pojęcia profesora w rozumieniu formalnej pozycji naukowej. Brak z jednej strony twardych uregulowań prawnych, a z drugiej - niekonsekwencja, a w zasadzie brak oddolnej środowiskowej samoregulacji spowodowały, że bardzo szybko w przestrzeni publicznej zaczęło przybywać „profesorów”, albowiem nawet w sferze „wizytówkowej” zapis „prof. dr hab.” zaczą być wykorzystywany także przez osoby bez tytułu profesora. Odpowiedzia ze strony profesorów tytularnych stało się z kolei nadużywanie określenia profesor zwyczajny, choć formalnie prawo do używania skrótu „prof. zw. dr hab.” miały coraz mniej liczne osoby, które uzyskały tytuł profesora zwyczajnego jeszcze w czasach PRL. Tę erozję pojęcia profesora utrwalają regulacje ustawy z 2018 r., w której zawarto zdecydowane rozszerzenie możliwości powoływania na stanowiska profesorskie osób bez habilitacji i co więcej, wprowadzono pojęcie profesorów dydaktycznych. Z jednej strony to rozwiązanie jest swoistym nawiązaniem do tradycji przedwojennej, w której, jak o tym pisałem, tytuły docenta i stanowiska profesorów nadzwyczajnego i zwyczajnego miały wyraźny wymiar dydaktyczny, a nie czysto naukowy. $\mathrm{Z}$ drugiej jednak strony rozwiązania dotyczace stanowisk profesorskich zawarte w ustawie z 2018 r. można traktować jako kolejny krok w stronę swoistego zachęcania środowiska akademickiego do zastanowienia się, czy tradycja ty-

15 Ustawa z 12 września 1990 r. o szkolnictwie wyższym, Dz. U. 1990, Nr 65, poz. 385. 
tułu profesorskiego, nadawanego ostatecznie przez prezydenta $R P$, ma sens. Czy w gruncie rzeczy nie powinno być tak, jak w stanowiącym dla niektórych uczestników debaty o awansach naukowych w Polsce wzorcu anglosaskim, a zwłaszcza amerykańskim, gdzie w zasadzie wszystkie kwestie awansowe sa rozstrzygane w ramach konkretnej uczelni, co nie znaczy, że nie towarzyszy im procedura kwalifikacyjna, czasem bardziej wymagającą od tej, którą trzeba przejść, by zostać profesorem tytularnym w Polsce.

Jeszcze więcej dyskusji niż kwestia tytułu profesora budzi utrzymywanie stopnia doktora habilitowanego ${ }^{16}$. Ustawa o tytule naukowym i stopniach naukowych z $1990 \mathrm{r}$. zachowała elementy istotnej zewnętrznej kontroli procesu habilitacji, jakim była konieczność zatwierdzania uchwał o nadaniu stopnia doktora habilitowanego przez Centralną Komisję do spraw Tytułu naukowego i Stopni Naukowych. To właśnie ten element szczególnej roli ówczesnej Centralnej Komisji, występujący także w wypadku postępowań związanych z nadawaniem tytułu profesora, w znacznej mierze przyczynił się do rozwoju swoistej czarnej legendy funkcjonowania tej organizacji. Obrońcy tego rozwiązania podkreślali, że - niestety - na poziomie części jednostek naukowych prowadzących postępowania raz po raz dawały o sobie znać elementy tak bliskiego instytucjonalistom pojęcia tradycji i różnych innych instytucji o charakterze nieformalnym, w których istotną rolę odgrywały lokalne i nie tylko lokalne więzi personalne. Swoista zasada, że swoich trzeba bronić, skutkująca niekiedy przykładaniem różnej miary do kandydatów z własnego środowiska i osób spoza niego czy kierowanie się w decyzjach niekoniecznie obiektywnymi przesłankami (a np. czasem bardziej pozycją nieformalnego promotora czy też patrona danej osoby) to tylko przykłady tego, co raz po raz skutkowało co najmniej dyskusyjnymi decyzjami na szczeblu konkretnych jednostek.

W tle rozwiązań przypisujących ówczesnej CK prawo do zanegowania całego postępowania i jego wyniku na poziomie danej jednostki był też wskazywany już problem braku zaufania i ryzyko dla państwa, które firmowało stopnie naukowe i tytuł naukowy jako „państwowe”, a zarazem nie miało zaufania, że interesariusze lokalni będą zawsze i na pewno kierować się nadrzędnością troski o rozwój nauki nad swoiście pojmowaną życzliwością w stosunku do konkretnej osoby.

Ustawa z 1990 r. nie rozwiązywała problemu, który już wcześniej dawał o sobie znać, a który wiąże się ze znanym z nowej ekonomii instytucjonalnej pojęciem oportunizmu ex post, w polskiej literaturze określanego albo jako ryzyko moralne albo - co jest lepszym rozwiązaniem - pokusa nadużycia. Najogólniej chodzi o sytuację, w której podmiot uzyskujący nadmierną ochronę (np. z tytułu zawartej umowy) przestaje być zainteresowany czy to unikaniem zdarzeń ryzykownych (sytuacja znana zwłaszcza ubezpieczycielom), czy to realizacją innych, pożądanych przez drugą stronę umowy działań. Pokusa

${ }^{16}$ Obrońcy utrzymywania habilitacji wskazują m.in. na jej rolę jako niezbędnego ogniwa troski o jakość wobec słabości innych oddolnych elementów systemu zapewniania jakości nauki i kadr naukowych. Por. Brzeziński (2015). Ten sam autor zawarł szczegółową analizę kwestii związanych z habilitacjami w okresie po 1990 r. w opracowaniu: Brzeziński (2017). 
nadużycia była w praktyce wyraźna, zwłaszcza jako konsekwencja habilitacji. Albowiem wraz z osiagnięciem stopnia doktora habilitowanego nauczycielom akademickim przestawało grozić ryzyko tzw. rotacji w wyniku braku odpowiednich rezultatów pracy naukowej. Ponieważ staranie się o tytuł naukowy nie miało charakteru obligatoryjnego, a na dodatek ustawa z 1990 r. dawała możliwość objęcia bezterminowo stanowiska profesora nadzwyczajnego, co w niektórych uczelniach następowało prawie automatycznie po pomyślnym zakończeniu postępowania habilitacyjnego, to w zasadzie dalsza aktywność naukowa stawała się w jakiejś mierze kwestią przede wszystkim motywacji wewnętrznej, a nie wyraźnego oddziaływania bodźców zewnętrznych.

Kolejną istotną zmianą w sferze regulacji awansów naukowych w Polsce było przyjęcie 14 marca 2003 r. ustawy o stopniach naukowych i tytule naukowym oraz o stopniach i tytule $\mathrm{w}$ zakresie sztuki ${ }^{17}$ i zwiąane $\mathrm{z}$ jej wejściem w życie powołanie nowego organu, czyli Centralnej Komisji do spraw Stopni i Tytułów, która została zlikwidowana wraz z końcem 2020 r., kiedy to nastapiło ostateczne przejęcie spraw awansów naukowych przez Radę Doskonałości Naukowej ${ }^{18}$. Ustawa z 2003 r. w swej pierwotnej wersji zawierała wiele rozwiązań wzorowanych na ustawie z 1990 r., a w tym konieczność zatwierdzania uchwał o nadaniu stopnia doktora habilitowanego przez CK. Jednakże w wyniku kolejnych nowelizacji, a zwłaszcza tych zawartych w ustawie z 27 lipca 2005 r. - Prawo o szkolnictwie wyższym ${ }^{19}$ i w ustawie z 18 marca 2011 r. o zmianie ustawy - Prawo o szkolnictwie wyższym, ustawy o stopniach naukowych i tytule naukowym oraz o stopniach i tytule w zakresie sztuki oraz o zmianie niektórych innych ustaw ${ }^{20}$, wprowadzono kilka bardzo istotnych zmian.

Szczególnie brzemienna w skutki okazała się decyzja o wyeliminowaniu możliwości zakwestionowania przez CK wyniku postępowania prowadzonego przez jednostkę naukową. Jedynie w sytuacjach skrajnych CK mogła wszczynać procedurę popularnie nazywana procedura kontrolna, a w rzeczywistości będąca procedurą oceny przeprowadzanych w danej jednostce postępowań, co mogło skutkować ograniczeniem, a nawet odebraniem uprawnień do nadawania stopnia doktora i/ lub stopnia doktora habilitowanego. Rozwiazania wprowadzone w 2011 r. czyniły z CK w znacznej mierze „żyranta” nie swoich decyzji, który nie mógł, poza wskazanymi procedurami oceny i udziałem w postępowaniach odwoławczych wszczynanych wyłącznie na wniosek osoby ubiegającej się o nadanie stopnia, w żaden sposób „korygować” zachowań i decyzji faktycznych decydentów na poziomie konkretnej jednostki.

17 Ustawa z 14 marca 2003 r. o stopniach naukowych i tytule naukowym oraz stopniach i tytule w zakresie sztuki, Dz. U. 2003, Nr 65, poz. 595.

18 Zakończenie funkcjonowania Centralnej Komisji zbiegło się z wydaniem książki ilustrującej historię i uwarunkowania prawne związane z funkcjonowaniem tej organizacji także w kontekście historycznym. Zob. Centralna Komisja do Spraw Stopni i Tytułów (2020).

19 Ustawa z 27 lipca 2005 r. - Prawo o szkolnictwie wyższym, Dz. U. 2005, Nr 164, poz. 1365.

${ }^{20}$ Ustawa z 18 marca 2011 r. o zmianie ustawy - Prawo o szkolnictwie wyższym, ustawy o stopniach naukowych i tytule naukowym oraz o stopniach i tytule w zakresie sztuki oraz o zmianie niektórych innych ustaw, Dz. U. 2011, Nr 84, poz. 455. 
Wyrazem podnoszonego już kilkukrotnie problemu braku czy też ograniczonego zaufania, w tym wypadku ze strony państwa do środowiska akademickiego, były dwa rozwiazania zawarte we wspominanej ustawie z $2011 \mathrm{r}$. Pierwsze dotyczyło upoważnienia ministra odpowiedzialnego za naukę do wydania rozporządzenia określającego kryteria oceny osiagnięć osoby ubiegającej się o nadanie stopnia doktora habilitowanego. Wraz z wydanym na podstawie tej delegacji ustawowej 11 września 2011 r. rozporządzeniem ${ }^{21}$ minister, a nie samo środowisko akademickie, określił, jakie kryteria powinni brać pod uwagę recenzenci, a także i inni uczestnicy postępowań habilitacyjnych. To wraz z tym rozporządzeniem wkroczyła na dobre, do dyskusji o ocenie efektów pracy naukowej na poziomie postępowań awansowych, bibliometria i takie pojęcia, jak indeks Hirscha czy sumaryczny impact factor. Drugim wyrazem braku zaufania do samoregulacji środowiskowej było odebranie CK prawa do określania dziedzin nauki sztuki oraz dyscyplin naukowych i artystycznych. Niestety lista dziedzin, a zwłaszcza dyscyplin naukowych, w okresie gdy o tym decydowała CK, zaczęła gwałtownie rosnąć na skutek dodawania już istniejącej dyscypliny do kolejnych dziedzin lub nadawania subdyscyplinom statusu dyscypliny naukowej.

Wspominane rozporządzenie regulujące kryteria związane $\mathrm{z}$ nadawaniem stopnia doktora habilitowanego, jak i cały proces zmian związanych z wejściem w życie regulacji dotyczących habilitacji wynikających z ustawy z 2011 r., jest przykładem z jednej strony częściowej kontrproduktywności działań legislacyjnych, a z drugiej - nadrzędności instytucji nieformalnych nad instytucjami formalnymi oraz dostosowywania się do bodźców. Co oczywiste, zmiany legislacyjne z $2011 \mathrm{r}$. były motywowane troską o poprawę jakości polskiej nauki i kadr akademickich. Jednakże, skądinąd konieczny, okres przejściowy pomiędzy wejściem w życie nowych rozwiązań legislacyjnych dotyczących habilitacji a obowiązywaniem nadal rozwiązań poprzednich spowodował „wysyp” wniosków, z których część stanowiły wnioski ewidentnie, jak to często określają opiniodawcy niechcący wprost sformułować opinii negatywnej, ,przedwczesne”. Niestety w sytuacji ogromu pracy, jaki wiązał się z koniecznością przeprowadzenia wszystkich procedur oraz nadal kluczowej roli lokalnych decydentów w postaci rad wydziałów czy rad jednostek, których pracownikami byli na ogół kandydaci, zdecydowanie rosło ryzyko akceptacji owych „przedwczesnych” wniosków. Kolejną odsłoną owej częściowej kontrpoduktywności były zmiany legislacyjne związane z wejściem w życie ustawy z 2018 r. I znowu, podobnie jak w roku 2012, okres przejściowy spowodował lawinowy wzrost wniosków, zwłaszcza habilitacyjnych, a w mniejszym stopniu profesorskich, i znowu wyraźnie wzrosło ryzyko akceptacji wniosków „przedwczesnych”.

O nadrzędności instytucji nieformalnych, w ramach których w polskiej tradycji mieści się między innymi swoiste poszanowanie daleko idącej suwe-

${ }^{21}$ Rozporządzenie Ministra Nauki i Szkolnictwa Wyższego z 1 września 2011 r. w sprawie kryteriów oceny osiagnięć osoby ubiegającej się o nadanie stopnia doktora habilitowanego, Dz. U. 2011, Nr 196, poz. 1165. 
renności opiniodawcy w sporządzaniu recenzji, także w odniesieniu do jej strony formalnej, świadczy to, że istotna część recenzji sporządzanych po $2011 \mathrm{r}$., czyli po wejściu w życie wskazywanego rozporządzenia, w ograniczonym stopniu albo tylko pośrednio odwoływała się do szczegółowych kryteriów w tymże rozporządzeniu zawartych, koncentrując się na kryteriach ogólnych i tradycyjnych, z podziałem na ocenę aktywności naukowej, dydaktycznej i organizacyjnej.

Z kolei wyrazem reakcji na bodźce zaczęły być chociażby autoreferaty kandydatów do stopni doktora habilitowanego, w których formalna dbałość o dopasowanie się do zawartych w rozporządzeniu kryteriów oceny skutkowała niekiedy elementami tego, co w nowej ekonomii instytucjonalnej, określa się mianem oportunizmu ex ante. Oportunizm ex ante wiąze się z idea, że podmiot, który dąży do uzyskania jakiegoś efektu, może nie zawsze postępować zgodnie z regułami fair play (np. podając niepełne lub „wystylizowane” informacje). W autoreferatach habilitacyjnych raz po raz widoczne to było zwłaszcza we fragmentach, w których autorzy podawali informacje o swoim udziale we współpracy międzynarodowej czy projektach badawczych. Kilkudniowe pobyty zagraniczne o charakterze krótkich wizyt studyjnych, i to raczej dydaktycznych, urastały do rangi istotnych przejawów zaangażowania w międzynarodowe działania badawcze, a badania w ramach tzw. badań własnych czy statutowych stawały się kierowanymi przez kandydata projektami badawczymi. Czasem taka strategia okazywała się skuteczna, bo - co oczywiste - nie wszyscy recenzenci czy członkowie komisji habilitacyjnych, nawet jeśli dostrzegali dyskusyjność pewnych informacji, traktowali to zarazem jako istotne uchybienie.

To pod rządami ustawy z 2003 r. nastapiła także kolejna bardzo istotna zmiana, jaką było wprowadzenie w 2014 r. możliwości ubiegania się o stopień doktora habilitowanego nie na podstawie ,jednotematycznego cyklu publikacji”, ale na podstawie „cyklu publikacji powiązanych tematycznie”. Niestety ta zmiana, która miała na celu dalsze rozszerzenie możliwości ubiegania się o stopień doktora habilitowanego bez konieczności przygotowywania monografii, przyczyniła się do wzrostu wniosków, w których głównym osiagnięciem naukowym stawał się bardzo luźny zbiór publikacji, którego spoiwem były na przykład wyłącznie niektóre powtarzajace się, a i to nie we wszystkich opracowaniach, słowa kluczowe czy, de facto określana dopiero na etapie pisania autoreferatu, jakaś wspólna idea czy cel. Na takie zbiory zaczęły się coraz częściej składać publikacje w języku angielskim. Tyle tylko, że konsekwencja owej reakcji na bodźce w tym wypadku wskazujących na potrzebę wykazywania się publikacjami obcojęzycznymi był (np. w obszarze najbliższym autorowi, czyli w obrębie nauk ekonomicznych) wzrost publikacji polskich autorów, czytelnych ze względu na lokalny kontekst rozważań dla tak naprawdę polskich odbiorców i wydawanych przez polskich wydawców tyle tylko, że w języku angielskim. Publikacje te często nie miały za bardzo szansy na zaistnienie w obiegu międzynarodowym, ale zapewniały autorom poprawę oceny przy okazji ubiegania się o habilitację w ramach dość miękko interpretowanego wymogu umiędzynarodowienia wyników aktywności naukowej. 
Skutkiem uznania przez ministra, że sposobem na poprawę jakości nauki i badań naukowych będzie oficjalne zwiększenie roli bibliometrii, był także wyraźny wzrost popularności niektórych czasopism zagranicznych indeksowanych w odpowiednich bazach i mających dodatni impact factor, a zarazem niekiedy stosujących dość miękką politykę kwalifikacji prac do druku, powiązaną nierzadko z nakładaniem na potencjalnych autorów określonych ciężarów finansowych, tłumaczonych różnymi przesłankami (od potrzeby finansowania kosztów redakcji językowej po zapewnienie możliwości funkcjonowania danego czasopisma w systemie tzw. otwartego dostępu) ${ }^{22}$.

Oczywiście tego, co napisałem, nie należy interpretować jako podważania idei potrzeby publikowania w języku angielskim, bo to po prostu daje znacznie większą szansę dostrzeżenia na arenie międzynarodowej wyników badań polskich uczonych. Nie jestem także przeciwnikiem samej bibliometrii, choć dostrzegam słabości posługiwania się nią w praktyce, związane z nieuwzględnianiem różnic między bibliometria a naukometrią ${ }^{23}$ i pomijaniem całego tła różnych mierników ${ }^{24}$. Rozumiem także przesłanki przemawiające za tworzeniem różnych baz czy list czasopism i wydawnictw. Zwracam jedynie uwagę na istotne słabości tych rozwiązań i wywoływanie często nie tyle następstw $\mathrm{w}$ postaci autentycznego wzrostu jakości badań naukowych, ile w postaci wkładania wysiłku przez część badaczy w zrozumienie szczegółów reguł gry ustalonych na przykład przez ministra i dopasowywanie się do nich. Nawet jeśli przyjąć w ślad za nową ekonomią instytucjonalna, że ludzi charakteryzuje nie pełna, a ograniczona racjonalność, to i tak oznacza to, że nie da się zmieniać reguł gry, w interesującym nas wypadku dotyczących awansów naukowych, zakładając bierność reakcji interesariuszy, którzy w ramach tych zmienianych reguł dążą do realizacji swoich celów ${ }^{25}$.

Kończąc fragment dotyczący okresu obowiązywania ustawy z 2003 r., warto jeszcze przypomnieć kwestię tzw. habilitacji słowackich (choć nie tylko słowackich $)^{26}$. I znowu jest to znakomity przykład funkcjonowania rozwiązań legislacyjnych z jednej strony i świata instytucji nieformalnych na szczeblu konkretnych organizacji akademickich. Obowiązujacca do 2016 r. umowa miedzy Polska a Słowacja zapewniała automatyczne uznawanie stopni naukowych uzyskanych na Słowacji za równoważne z ich odpowiednikami w Pol-

${ }^{22}$ Funkcjonowanie tzw. predatory journals, czyli czasopism drapieżnych, zostało w swoim czasie znakomicie zilustrowane w opracowaniu: Kulczycki (2017).

${ }^{23}$ O różnicach tych, w kontekście szerszej refleksji o naukoznawstwie i odniesień do polskich realiów, pisze m.in. Kokowski (2015a) i (2015b).

${ }^{24}$ Przykładem może być słynny esej Francisa Fukuyamy o końcu historii, który doczekał się imponującej liczby cytowań i istotnie wpłynął na wskaźniki bibliometryczne autora, a który to esej, po okresie początkowego niezwykle pozytywnego przyjęcia, później zaczął być coraz częściej cytowany w ramach mniej lub bardziej otwartej polemiki z autorem.

25 Odrębną i wykraczającą poza ramy opracowania kwestią jest cały mechanizm kształtowania list czasopism czy wydawnictw, dopuszczania konkretnych wydawców do uwzględnienia w ramach konkretnych baz danych czy objęcia procesem indeksacji. Samo w sobie jest to zagadnienie warte odrębnej analizy, właśnie w kategoriach ekonomii instytucjonalnej.

${ }^{26}$ Szczególnie aktywny w nagłaśnianiu tego problemu był Bogusław Śliwerski, który poświęcił tej kwestii także opracowanie monograficzne: Śliwerski (2018). 
sce $^{27}$. W zasadzie z tej możliwości mogła skorzystać każda osoba zamierzająca ubiegać się o stopień doktora habilitowanego. A jednak to w ramach konkretnych dyscyplin naukowych i organizacji akademickich nastapiła wyraźna koncentracja takich działań. Przyczyna w znacznej mierze tkwiła w czymś, czego nie jest w stanie uregulować prawo, czyli gotowości akceptacji lub nie pewnych zachowań w danym środowisku. Ponieważ, jak już wskazywano, ludzie sa racjonalni, to skoro na konkretnej uczelni panował swoisty klimat akceptacji dla turystyki naukowej na Słowację, to różne osoby z tego korzystały. Ale wystarczyło, aby w innej uczelni rektor wysłał wyraźne sygnały, że nie jest to zachowanie pożądane, aby zdecydowanie takie działania ograniczyć, a nawet wyeliminować.

Jak już pisałem, ustawa z 20 lipca 2018 r. - Prawo o szkolnictwie wyższym i nauce zastapiła cały pakiet ustaw wcześniej obowiązujących, a w tym odrębną ustawę regulujaçą kwestie traktowane jako wiążące się z funkcjonowaniem szkolnictwa wyższego i tę odnoszaccą się do kwestii awansów naukowych. Utrzymano, mimo często mocnej krytyki tego rozwiązania, dotychczasowe dwa stopnie naukowe i tytuł naukowy oraz ich odpowiedniki w obrębie sztuki. Powołano nową instytucję centralną, czyli Radę Doskonałości Naukowej (RDN), której skład odzwierciedla nowa, wprowadzoną decyzją ministerialną i bardzo ograniczona w stosunku do poprzednich rozwiązań, klasyfikację dziedzin i dyscyplin naukowych ${ }^{28}$.

W kwestiach procedur obowiązujących przy ubieganiu się o habilitację i tytuł profesora wprowadzono dość istotne zmiany, po części odzwierciedlajace podnoszony kilkukrotnie problem ograniczonego zaufania państwa do samoregulacji środowiskowej. W wypadku habilitacji polega to między innymi na tym, że przyjęto, zdaniem autora opracowania, kontrowersyjną zasadę, że w sytuacji dwóch recenzji negatywnych na cztery, które sa przygotowywane, komisja habilitacyjna automatycznie wydaje negatywną opinię. Zasada ta jest kontrowersyjna, bo de facto oparta jest na założeniu, że przy pewnym poziomie wątpliwości, w tym wypadku wyrażonego dwiema negatywnymi recenzjami, automatycznie i bez analizy szczegółów tychże recenzji oraz bez ich konfrontacji z pozostałymi określony zostaje wynik całego postępowania. W praktyce może to skutkować jeszcze mniejszą gotowością do formułowania przez recenzentów konkluzji negatywnych, niechcacych doprowadzić do negatywnego wyniku postępowania bez możliwości dyskusji w ramach komisji.

${ }^{27}$ W tym miejscu, nawiązując do krytyki Ministerstwa Nauki i Szkolnictwa Wyższego za tolerowanie tej sytuacji, chciałbym zauważyć, że do wypowiedzenia umowy potrzebna była zgodna wola reprezentantów obu krajów.

${ }^{28}$ Warte odrębnej analizy byłoby porównanie starej klasyfikacji z nową i pierwowzorem tej nowej, czyli tzw. klasyfikacją OECD, określoną przez tę organizację wyłącznie w celu zapewnienia możliwości porównań rozwiązań obowiązujących w poszczególnych krajach, a nie jako swego rodzaju wzorzec do naśladowania. Warto także zauważyć, że dwie dziedziny, które zniknęły w nowej klasyfikacji obowiązującej w Polsce w ramach nauk społecznych, to nauki ekonomiczne i nauki prawne. $\mathrm{Z}$ tym że o ile nazwa nauki prawne pozostała na poziomie dyscypliny, to nazwa nauki ekonomiczne została całkowicie wyeliminowana, a cztery wcześniej funkcjonujące dyscypliny skumulowano do dwóch. 
Przyjęcie wskazanego powyżej rozwiązania jest przykładem mocno dyskusyjnej próby rozwiązywania za pomocą instytucji formalnych, polegających na konkretnej legislacji, problemów wynikających z funkcjonowania w praktyce instytucji nieformalnych zwiazzanych na przykład ze wspominaną wcześniej dużą rolą kwestii personalnych. Niestety w praktyce funkcjonowania ustawy z 2003 r. zdarzało się, że nawet w przypadku zdecydowanie negatywnej opinii komisji habilitacyjnej rady, podejmujace ostatecznie decyzje o nadaniu stopnia, przyjmowały uchwały korzystne dla kandydatów. W tym miejscu przypomnijmy także, że w pierwszych wersjach ustawy przyjętej ostatecznie w 2018 r. było wręcz przewidziane utajnianie dwojga spośród czworga recenzentów, co stanowiło skrajny wyraz braku zaufania do obiektywizmu procesu opiniodawczego. Wyrazem chęci osłabienia potencjalnych zarzutów o brak obiektywizmu, co również wiąże się z problemem zaufania, jest także przyjęcie w ustawie z 2018 r. mocno dyskusyjnego rozwiązania losowania przez RDN recenzentów, zarówno w wypadku postępowań habilitacyjnych, jak i postępowań o nadanie tytułu profesora, z puli trzykrotnie przewyższającej wymagana liczbę opiniodawców.

Nie realizując idei odstapienia od habilitacji, w ustawie z 2018 r. znalazły się zapisy wyraźnie osłabiające jej znaczenie i stanowiące wyraz miękkiego zachęcania środowiska akademickiego i naukowego do odstapienia, z czasem, od obrony habilitacji jako stopnia naukowego. O takim „rozmiękczaniu” znaczenia habilitacji świadczy zarówno likwidacja zapisów świadczących o jej niezbędności dla utrzymania statusu nauczyciela akademickiego, wspominane już zdecydowane rozszerzenie możliwości obejmowania stanowiska profesora uczelni przez osoby bez habilitacji oraz zapisy niepozwalajace uczelniom na wprowadzanie, w ramach własnych rozwiazań regulacyjnych, wymogu habilitacji jako dodatkowego warunku dla osób ubiegających się o określone stanowiska. Ustawa z 2018 r. nie zawiera delegacji dla ministra odpowiedzialnego za naukę do wydania rozporządzenia regulującego warunki ubiegania się o habilitację. Pewne elementy już nieobowiązującego rozporządzenia zawarte są bezpośrednio w ustawie, a dotyczy to w szczególności wymogów, jakie muszą spełniać publikacje ilustrujące znaczny wkład do danej dyscypliny naukowej. Znacznie mniej precyzyjne są zapisy dotyczące na przykład wymogu aktywności naukowej realizowanej w więcej niż jednej uczelni czy jednostce naukowej, zwłaszcza że w Polsce nadal podstawowy model kariery akademickiej wiąże się, z wielu względów, z realizacją kariery akademickiej w ramach jednej organizacji.

W wypadku ubiegania się o tytuł profesora novum polega na całkowitym przejęciu tego postępowania przez RDN. Zrezygnowano z budzącego wiele kontrowersji, ze względu na bardzo istotne różnice między poszczególnymi dyscyplinami i dziedzinami nauki, wymogu udziału w rozwoju kadr naukowych udokumentowanego rola promotora czy promotora pomocniczego w postępowaniach związanych $\mathrm{z}$ nadaniem stopnia doktora, a na miejsce zapisu o wymogu istotnego powiększenia dorobku po habilitacji pojawił się bardzo nieprecyzyjny zapis o wybitnych osiagnięciach naukowych ${ }^{29}$. Ustawodawca

\footnotetext{
${ }^{29} \mathrm{Na}$ potencjalne problemy z tym związane zwrócono m.in. uwagę w: Wiktor (2019).
} 
zapewne chciał zasygnalizować w ten sposób wizję tytułu profesora jako szczególnego wyróżnienia dla liderów aktywności naukowej. W przekonaniu autora opracowania praktyka najprawdopodobniej będzie zbliżona mniej lub bardziej do tradycji dotychczasowej, czyli traktowania tytułu profesora jako kolejnego etapu formalnego awansu naukowego, dostępnego dla wszystkich, którzy spełnia pewne mniej lub bardziej explicite sformułowane wymogi. Nie można wykluczyć, że w praktyce funkcjonować będą na przykład pewne wymogi zwyczajowe, takie jak tzw. książka profesorska. Książka profesorska to kolejny przykład roli instytucji nieformalnych o charakterze zwyczajowym, bo choć ustawa z 2003 r. takiego wymogu nie przewidywała, to w praktyce, zwłaszcza nauk humanistycznych, społecznych czy ekonomicznych, w wypadku większości wniosków kluczowym elementem udokumentowania przyrostu dorobku po uzyskaniu habilitacji były monografie, popularnie określane właśnie mianem książek profesorskich.

W zasadzie wszystkie ustawy przyjmowane po 1990 r., a regulujące sferę szkolnictwa wyższego i nauki oraz awansów naukowych akcentowały szczególną rolę wolności badań naukowych, autonomii akademickiej i organizacji opartych na idei samorządności środowiska akademickiego. Nie znaczy to jednak, że wskazywany kilkukrotnie problem władczości państwa zniknął. Państwo nie zamierzało ani nie zamierza rezygnować z traktowania szkolnictwa wyższego i nauki jako obszarów, w ramach których realizuję swoją politykę, choć - co trzeba podkreślić - niestety raczej bardziej w rozumieniu angielskiego określenia politics, odzwierciedlającego często doraźne cele i oczekiwania związane na przykład z utrzymaniem czy umocnieniem władzy przez konkretną ekipę polityczna, niż w rozumieniu angielskiego terminu policy, czyli pewnej długookresowej polityki rozwoju danego obszaru życia społecznego i gospodarczego, bez kierowania się doraźnymi przesłankami politycznymi. Podjęta w lutym 2021 r. przez ministra edukacji i nauki arbitralna decyzja o zmianach na liście czasopism uznawanych za naukowe i przypisanej im punktacji jest klasycznym wyrazem dominacji politics.

Kończąc historyczny przegląd rozwiązań związanych z systemem awansów naukowych w Polsce i nawiązując do kilkukrotnie już podnoszonego problemu władzy, warto jeszcze zwróci uwagę na niezwykle istotną kwestię związana z rolą władzy sądowniczej. W ustawie z 2003 r. znalazły się zapisy wskazujące, że postępowania awansowe sa co prawda specyficznymi, ale jednak postępowaniami mającymi cechy postępowań administracyjnych, podlegającymi w zwiazku z tym Kodeksowi postępowania administracyjnego i kontroli sądowej. Zasadę tę utrzymano w ustawie z 2018 r. Sprawa administracyjnego charakteru postępowań awansowych jest o tyle istotna, że coraz częściej podmioty nieusatysfakcjonowane przebiegiem postępowań traktują drogę sądową jako swego rodzaju naturalny kolejny etap procedury odwoławczej. To przygotowanie do ewentualnego złożenia skargi do sądu administracyjnego widać już na poziomie odwołań, które coraz częściej pisane są przy udziale, czy wręcz przez prawników, którzy nadają im już na etapie odwoławczym w ramach jednostki prowadzącej postępowanie czy na poziomie CK (a dziś - RDN) formę pism przedprocesowych, z obfitym odwoływaniem się zarówno do konkretnych ak- 
tów prawnych, jak i ich wykładni zawartej w literaturze. Na dodatek praktyka przebiegu postępowań sądowych pokazuje, że sąd administracyjny coraz częściej odstępuje od koncentracji wyłącznie na formalnej i proceduralnej stronie postępowań i wchodzi w kwestie związane z merytoryczną stroną postępowań. Chodzi tu zwłaszcza o podnoszony często w odwołaniach zarzut niedostatecznego uzasadnienia uchwał odmawiających nadanie stopnia naukowego. Problem polega na tym, że nie ma przepisów, które nakładałaby na organy kolegialne, takie jak na przykład rady wydziałów czy rady dyscyplin, obowiązek poprzedzenia dyskusja głosowań dotyczacych uchwał o nadaniu lub odmowie nadania stopnia. Biorąc na dodatek pod uwagę tajny charakter głosowań, nikt z członków organu kolegialnego nie ma obowiazku uzasadnienia swojej decyzji o poparciu lub odmowie poparcia danego wniosku. W efekcie uzasadnienia takich uchwał często w zasadzie powinny sprowadzać się do wyimków z recenzji i protokołów posiedzeń komisji habilitacyjnych, co z kolei może rodzić zarzut dopasowywania argumentacji do wyników głosowania. Sprawa roli władzy sadowniczej jest o tyle istotna, że postępowania awansowe są w znacznej mierze i powinny być postępowaniami opartymi na elementach oceny jakościowej, trudnej do jednoznacznego udokumentowania w kategoriach prostego porównania na przykład wagi argumentów za i przeciw. Gdyby miało być inaczej, to proces recenzowania powinien być sprowadzony do prostej „,checklisty” i mierników ilościowych typu liczba zgromadzonych punktów, indeks Hirscha czy liczba cytowań w takiej czy innej bazie. Takie rozwiązanie, chroniące przed zarzutem subiektywizmu czy braku dostatecznego udokumentowania oceny, byłoby jednak całkowicie sprzeczne z ideą rozwoju nauki, którego nie da się sprowadzić do zbioru mierników ilościowych.

\section{UWAGI KOŃCOWE}

Ustawa z 2018 r. zapewne będzie tylko kolejnym etapem w zbiorze regulacji nauki i szkolnictwa wyższego. Etapem istotnym, ale przypisywanie mu roli absolutnie fundamentalnej czy rewolucyjnej jest przesadac. W ustawie zawartych jest wiele rozwiązań przejętych z ustaw wcześniejszych, a jak pokazano w tekście, niektóre sformułowania dotyczące na przykład wymogów stawianych kandydatom do habilitacji mają historię sięgającą zupełnie innych realiów ustrojowych. W przekonaniu autora nie można oczekiwać, że nowe regulacje, zarówno w zakresie wymogów stawianych kandydatom do stopni naukowych i tytułu naukowego, jak i związane z rozwiązaniami organizacyjnymi w tym zakresie, rozwiążą czy wyeliminuja problemy wynikające $\mathrm{z}$ istotnej roli szeroko rozumianych instytucji nieformalnych opartych na tradycji (nie zawsze dobrej i wartej kontynuacji), zwyczaju czy związanych z kwestią zaufania. Na podstawie własnego wieloletniego doświadczenia coraz bardziej skłaniam się do przekonania, że w dłuższej perspektywie nie ma niepodważalnych argumentów ani na rzecz utrzymania habilitacji, ani tytułu profesora nadawanego przez prezydenta RP. Za każdym razem, gdy zmieniano, i to nie- 
kiedy istotnie, rozwiąania legislacyjne, powtarzane były argumenty o znaczeniu tych zmian dla istotnej poprawy jakości badań naukowych i rozwoju nauki. To jednak nie rozwiązania legislacyjne o tym decyduja. Oczywiście moga one, poprzez wynikające $\mathrm{z}$ nich bodźce, zachęcać lub zniechęcać do konkretnych działań. Mogą podpowiadać, co w tym momencie jest przez ustawodawcę utożsamiane z pewnym wzorcem rozwoju naukowego i wyrazami uzyskiwania rezultatów świadczących o jakości procesu badawczego. Ale tylko tyle i nic więcej. Bo najistotniejsze są właśnie instytucje nieformalne odzwierciedlone w postawach osób wchodzacych w skład środowiska akademickiego. Tak jak to zilustrowano na przykładzie tzw. habilitacji słowackich, tam gdzie panowała atmosfera akceptacji i przyzwolenia, takich habilitacji było więcej niż tam, gdzie środowisko wyraźnie potrafiło artykułować brak uznania dla tej drogi awansowej. Bardzo dobrym przykładem roli lokalnej tradycji jest też budząca wiele dyskusji kwestia umarzania postępowań habilitacyjnych. I znowu w niektórych środowiskach lokalnych, wręcz na poziomie konkretnych rad, ukształtowała się tradycja bardzo miękkiego podejścia do takich wniosków i podejmowania decyzji o umorzeniu, nawet wtedy gdy wniosek wpływał już po przygotowaniu wszystkich recenzji i ze strony wnioskującego był ewidentnie podyktowany chęcią uniknięcia negatywnego wyniku postępowania. $\mathrm{W}$ innych społecznościach, w tym samym stanie prawnym, zdecydowanie przestrzegano zasady, że umorzenie nie może być sposobem na unikanie negatywnego wyniku postępowania habilitacyjnego.

Problem z instytucjami nieformalnymi polega na tym, że nie da się zadekretować ich zmiany, a zmiany samoistne sa często długotrwałe i nie zawsze musza być to zmiany na lepsze, poza tym instytucji tych nie da się transferować $^{30}$. Nie oznacza to oczywiście, że nie należy doskonalić rozwiązań legislacyjnych. Tyle tylko, że trzeba założyć, że nie da się znaleźć swoistego Świętego Graala legislacyjnego, który zapewni zawsze sprawiedliwe, równe i w pełni obiektywne traktowanie wszystkich aspirujących do kolejnych awansów naukowych. Cel pełnej porównywalności warunków ubiegania się o awans naukowy można by próbować osiagnąć, odwołując się do rozwiązania znanego z tradycji francuskiej, gdzie tzw. agregacja ma charakter egzaminu państwowego i na dodatek konkursowego, do którego może przystapić każdy spełniający określone warunki i którego zaliczenie daje przywileje związane między innymi z formalna pozycja akademicka.

Zmiany w systemie awansów naukowych w Polsce pokazują wyraźnie ewolucyjny, a nie rewolucyjny charakter zmian. Część rozwiązań obecnie obowiąujących sięga swymi korzeniami do tradycji jeszcze przedwojennej. Widać $\mathrm{w}$ zmianach systemu awansów naukowych w Polsce wyraźne elementy tego, co po angielsku określane jest mianem path dependence, czyli zależności od długookresowej ścieżki rozwoju. System awansów naukowych w Polsce jest także przykładem tego, że zmiany instytucji formalnych, w postaci norm prawnych, mają oczywiście znaczenie, ale często nie mniejszą, a nawet istot-

${ }^{30}$ Wiele ciekawych uwag związanych z tym, co autor opracowania nazywa wpływem instytucji nieformalnych, zwartych jest w Antonowicz (2015). 
niejszą rolę odgrywają instytucje o charakterze norm nieformalnych, związanych z takimi kwestiami, jak tradycja, zwyczaj, czy to wszystko, co wiąże się z dyskusją o zaufaniu i reakcją na bodźce tudzież zachowaniami ludźmi, $\mathrm{w}$ których występuja elementy oportunizmu zarówno ex ante, jak i ex post. Biorac pod uwage zjawisko zależności od ścieżki, w Polsce, w sferze regulacji dotyczących systemu awansów naukowych, najbardziej prawdopodobny wydaje się scenariusz kolejnych zmian rozwiązań regulacyjnych, za każdym razem prezentowanych jako kamienie milowe w działaniach na rzecz poprawy jakości nauki, a zarazem stanowiących wypadkowa ścierania się przesłanek, które powinny określać długookresowa politykę państwa wobec sektora nauki i szkolnictwa wyższego, z tymi, które odzwierciedlać będą doraźne motywy polityczne konkretnych ugrupowań politycznych czy wręcz konkretnych polityków oraz oczekiwań i postulatów samego środowiska akademickiego i naukowego, a przynajmniej tej części tych postulatów, które będą najwyraźniej artykułowane przez dominujących w tym środowisku interesariuszy ${ }^{31}$. Znacznie mniej prawdopodobny wydaje się scenariusz rzeczywiście rewolucyjnej zmiany w systemie awansów naukowych, która opierałaby się na założeniu, że nie da się drogą zmian instytucji formalnych o charakterze norm prawnych skutecznie rozwiązywać problemów, które mają swoje źródło w znacznej mierze w instytucjach nieformalnych mających na dodatek często wyraźny rys czy wymiar lokalny, wyznaczony granicami konkretnej organizacji akademickiej czy naukowej.

Antonowicz, D. (2015). Między siłą globalnych procesów a lokalną tradycją. Polskie szkolnictwo wyższe w dobie przemian. Toruń: Wyd. Nauk. UMK.

Brzeziński, J.M. (2015). O konieczności utrzymania habilitacji w Polsce. Nowotwory. Journal of Oncology 65(4): 292-297.

Brzeziński, J.M. (2017). O poprawianiu (ale też i o psuciu) systemu przeprowadzania awansów naukowych w Polsce w latach 1990-2017. Nauka i Szkolnictwo Wyższe 2(50): 148-172.

Centralna Komisja do spraw Stopni i Tytułów (1991-2020), (2020). Warszawa: Centralna Komisja do Spraw Stopni i Tytułów.

Izdebski, H., Zieliński, J.M. (2019). Prawo o szkolnictwie wyższym i nauce. Komentarz. Wolters Kluwer.

Kokowski, M. (2015a). Jakiej naukometrii i bibliometrii potrzebujemy w Polsce. Polska Akademia Umiejętności - Prace Komisji Historii Nauki PAU 14: 135-184.

Kokowski, M. (2015b). Szkic aktualnej debaty nad naukometrią i bibliometrią w Polsce i zapomniane naukoznawstwo. Polska Akademia Umiejętności - Prace Komisji Historii Nauki PAU 14: 118-134.

Kulczycki, E. (2017). Kariera drapieżnych czasopism - przypadek Anny O. Szust. Nauka 3: 71-83. North, D.C. (2007). Instytucje, ideologia i wyniki gospodarcze. Tłum. D. Milczarek-Andrzejewska. Warszawa: Forum Obywatelskiego Rozwoju.

North, D.C. (1992). Institutions, Ideology and Economic Performance. Cato Journal 11(3): 477-496.

${ }^{31}$ Proces dochodzenia do rozwiązań zawartych w ustawie z 2018 r. był znakomitym przykładem takiego dopasowywania się wskazanych trzech elementów oddziałujacych na zmiany prawa. Odrębną i ciekawą kwestią byłoby przeanalizowanie niektórych przyjętych ostatecznie rozwiązań przez pryzmat dyskusji o grupach interesów, w tym wypadku w środowisku akademickim, i skuteczności ich lobbingu. 
Przeniosło, M. (2011). Habilitacje w II Rzeczypospolitej (na przykładzie matematyków). Rocznik Łódzki 58: 59-72.

Przeniosło, M. (2017). Ścieżki awansu naukowego w II Rzeczypospolitej. Forum Akademickie 07/08.

Śliwerski, B. (2018). Turystyka habilitacyjna Polaków na Słowację w latach 2005-2016. Studium krytyczne. Łódź: Wydawnictwo Uniwersytetu Łódzkiego.

Wiktor, J. (2019). Recenzja osiagnięć naukowych w postępowaniach awansowych - między jakością oceny a formalizmem rozstrzygnięć Ustawy 2.0. E-mentor 1(78): 4-10.

Wojtczak, K. (2017). Habilitacje w Polsce Ludowej. Część 1. Warunki i przebieg habilitacji w prawie szkół wyższych. Studia Prawa Publicznego 1(17): 25-61.

Wojtczak, K. (2018). Tytuł profesora w Polsce w latach 1920-1990. Część 2. Warunki nadawania tytułu profesora w prawie o stopniach i tytułach naukowych. Studia Prawa Publicznego 1(21): 31-52.

\section{THE SYSTEM OF ACADEMIC ADVANCEMENT IN POLAND: EVOLUTION AND INSTITUTIONAL ASPECTS}

\section{Sum mary}

The aim of the paper is to present, from a historical perspective, the evolution of the system of academic advancement in Poland, with particular emphasis on solutions from the period following the start of the political transformation. The author uses elements of the analysis and conceptual apparatus typical for institutional economics, both in the variant sometimes referred to as the old institutional economics, and in the so-called new institutional economics. The analysis of changes in the system of academic advancement in Poland in the period after independence was regained in 1918, and especially in the period after World War II, shows that the changes were clearly evolutionary, rather than revolutionary. This occurred with clear path dependence and the important role, next to formal institutions related to legislative changes, of informal institutions in the area of tradition, custom and discussion about the response to incentives.

Keywords: academic advancement; formal and informal institutions; evolution 
